\title{
PENERAPAN METODE HANLON DALAM MEMPRIORITASKAN PENGEMBANGAN APLIKASI SISTEM INFORMASI STUDI KASUS: BADAN PENGAWAS XYZ
}

\author{
Hendri Irawan', Irawan $^{2}$, Joko Christian \\ ${ }^{1}$ Fakultas Teknologi Informasi, Program Studi Sistem Informasi, Universitas Budi Luhur, Jakarta, Indonesia \\ ${ }^{2}$ Fakultas Teknologi Informasi, Program Studi Sistem Komputer, Universitas Budi Luhur, Jakarta, Indonesia \\ ${ }^{3}$ Fakultas Teknologi Informasi, Program Studi Manajemen Informatika, Universitas Budi Luhur, Jakarta, Indonesia \\ Email: ${ }^{1}$ hendri.irawan@ budiluhur.ac.id, ${ }^{2}$ irawan@budiluhur.ac.id, ${ }^{3}$ joko.christian@ budiluhur.ac.id
}

\begin{abstract}
Abstrak- Badan Pengawas XYZ (bukan nama sebenarnya) merupakan badan negara yang dibentuk berdasarkan undang-undang tahun 2007 tentang Lembaga Penyelenggara XYZ. Masalah yang dihadapi Badan Pengawas XYZ adalah banyaknya usulan rekomendasi kegiatan, mulai dari penyusunan dokumen-dokumen tata pamong, rencana strategis TI, dan rencana pengembangan aplikasi, hingga penguatan pada sisi keamanan jaringan semua dianggap penting oleh departemen yang mengusulkan dan harus segera direalisasikan. Namun tentu saja implementasi rekomendasi tersebut dibatasi oleh sumber daya yang ada seperti: biaya, waktu dan manusia. Sehingga perlu dilakukan penentuan prioritas dalam pelaksanaannya pada kurun waktu tertentu. Sudah dilakukan penelitian untuk menyelesaikan permasalahan tersebut dengan penggunaan metode Hanlon. Metode ini sesuai dalam menentukan prioritas yang lebih efektif dipergunakan untuk masalah yang bersifat kualitatif dan atau data / informasi yang tersedia bersifat kualitatif. Kondisi ini sangat cocok dengan data hasil kuesioner dan wawancara yang terkumpul. Pendekatan utama dalam metode ini adalah membandingkan tingkat kepentingan masalah / proses/ tujuan yang satu dengan yang lain menggunakan teknik "pencocokan" (matching) satu-per satu. Aktivitas yang dilakukan dalam penelitian ini termasuk melaksanakan wawancara semiterstruktur dengan para pemangku kepentingan untuk mendapatkan masukan dari sudut pandang individual/ grup terhadap tingkat urgensi sebuah sistem informasi / aplikasi. Selanjutnya Focus Group Discussion (FGD) yang dimoderatori oleh peneliti dengan menyertakan para pemangku kepentingan yang terkait. Hasil dari penelitian ini adalah daftar prioritas kegiatan yang akan dilakukan oleh Badan Pengawas XYZ pada rencana anggaran tahun berikutnya.
\end{abstract}

Kata Kunci: prioritas pengembangan aplikasi, metode Hanlon, prioritas kegiatan, wawancara semi-terstruktur, FGD

\begin{abstract}
Badan Pengawas XYZ (not the real name) is a state agency established under the 2007 law concerning Badan Pengawas $X Y Z$. The problems faced by Badan Pengawas XYZ, namely the amount of recommendation proposals, from the preparation of governance documents, IT strategic plans, and application development plans, until strengthening the network security, are all considered important by each promoting department and demanded to be realized immediately. But the implementation of those recommendations is limited by the available resources such as: cost, time and people. So, it is necessary to determine priorities in its implementation at a certain time. Research has been carried out to solve these problems, by using the Hanlon method. This method is suitable in determining priorities which are more effectively used for qualitative problems and / or the available data / information is qualitative. This condition is very suitable with the collected data from questionnaires and interviews. The main approach in this method is to compare the importance of the problem / process / goal between one another using one-by-one matching techniques. Activities carried out within this research consist of conducting semi-structured interviews with stakeholders to get input from an individual / group point of view on the level of urgency of an information system / application. Furthermore, the Focus Group Discussion (FGD), which was moderated by researchers, included related stakeholders. The results of this study are the list of priority activities that will be carried out by Badan Pengawas XYZ in the next year's budget plan.
\end{abstract}

Keywords: priority of application development, Hanlon method, priority of activities, semi-structured interviews, FGD

\section{PENDAHULUAN}

Badan Pengawas XYZ (bukan nama sebenarnya) merupakan badan yang dibentuk berdasarkan undang-undang Tahun 2007 tentang Lembaga Penyelenggara XYZ. Kemudian seiring dengan dinamika kelembagaan penyelenggara XYZ dan perkembangannya di Indonesia yang semakin dinamis, pencegahan dan penindakan terhadap penyelenggaraan XYZ dikuatkan melalui Undang-undang Tahun 2017. Dintaranya menyusun standar tata laksana pengawasan penyelenggaraan XYZ; melakukan pencegahan dan penindakan terhadap pelanggaran dan sengketa XYZ; mengawasi persiapan penyelenggaraan XYS; mengawasi pelaksanaan tahapan penyelenggaraan XSZ.

Dalam menjalankan proses bisnis, aktivitas, tugas pokok dan fungsinya Badan ini memerlukan dukungan aplikasi sistem informasi. Saat ini terdapat 32 aplikasi, dengan kondisi 26 aplikasi aktif, 3 aplikasi dalam pemeliharaan, 2 aplikasi dihentikan layanannya sementara, dan 1 yang tidak aktif.

Sejalan dengan dinamika situasi di Indonesia, mendorong Badan Pengawas XYZ untuk terus melakukan perbaikan dan inovasi guna memenuhi dan memberikan layanan terbaik kepada seluruh pemangku kepentingan (stakeholder). Agar usaha pemanfaatan sistem informasi berjalan seperti yang diharapkan diperlukan perencanaan kebutuhan yang baik. Keberhasilan tata kelola SI sangat ditentukan oleh keselarasan penerapan SI dan tujuan 
organisasi. Salah satunya mengetahui kondisi implementasi teknologi informasi saat ini untuk melakukan perencanaan pengembangan Sistem Informasi yang akan datang.

Dalam perkembangan teknologi dan sistem informasi banyak fasilitas serta fitur di dalamnya yang menjadikan kemudahan-kemudahan yang bisa berdampak pada proses bisnis.[1]

Permasalahan yang dihadapi Badan Pengawas XYZ yaitu usulan rekomendasi mulai dari penyusunan dokumendokumen tata pamong dan rencana strategis TI, rencana pengembangan aplikasi sistem informasi dan penguatan pada sisi keamanan jaringan semua dianggap penting oleh departemen yang mengusulkan dan harus segera direalisasikan.

Namun tentu saja hal ini dibatasi oleh sumber daya yang ada seperti biaya, waktu dan manusia. Sehingga perlu dilakukan penentuan prioritas dalam pelaksanaannya pada kurun waktu tertentu.

Berdasarkan latar belakang tersebut, peneliti mendapatkan pertanyaan riset sebagai berikut : "Metode atau kombinasi metode apakah yang cocok untuk membantu Badan Pengawas XYZ dalam menentukan prioritas pengembangan sistem informasi / aplikasi untuk perencanaan masa depan?"

Solusi untuk menyelesaikan permasalahan yang dihadapi yaitu dengan penggunaan metode yang harus memuaskan para stakeholder yang terkait, dalam kesepakatan bersama yang dapat dipahami semua pihak dan lugas. Pengumpulan data-data kualitatif dan mencoba menguantifikasikan data yang dihasilkan yaitu menggunakan metode Hanlon.

Metode Hanlon cocok untuk menentukan prioritas [2], dan lebih efektif dipergunakan untuk masalah yang bersifat kualitatif dan atau data / informasi yang tersedia bersifat kualitatif. Kondisi ini sangat cocok dengan data hasil kuesioner dan wawancara yang terkumpul. Pendekatan utama dalam metode ini adalah membandingkan tingkat kepentingan masalah/proses/tujuan yang satu dengan yang lain menggunakan teknik "pencocokan" (matching) satuper satu.

Kegiatan yang dilakukan melaksanakan wawancara semi-terstruktur dengan para stakeholder untuk mendapatkan masukan dari sudut pandang individual/ grup [3], terhadap tingkat urgensi sebuah sistem informasi/ aplikasi. Selanjutnya Focus Group Discussion (FGD) yang dimoderatori oleh peneliti dengan menyertakan para stakeholder yang terkait. Hasil dari penelitian ini adalah prioritas kegiatan yang akan dilakukan oleh Badan Pengawas XYZ pada rencana anggaran tahun berikutnya. FGD akan menghasilkan data kualitatif yang memberi gambaran dan pemahaman atas sikap, persepsi dan perasaan peserta, melalui pertanyaan terbuka. [4]

Langkah pengumpulan data termasuk mengatur batasan dari riset melalui sampling dan kebutuhan; mengumpulkan informasi melalui observasi dan wawancara yang semi terstruktur atau tidak terstruktur, dokumen, dan materi visual; juga menetapkan protokol untuk menyimpan informasi yang didapatkan.[5]

Sebagai studi literatur, peneliti mempelajari penelitian sejenis, sebagai berikut: Penelitian membahas tentang metode Hanlon untuk menyelesaikan permasalahan pada perencanaan pembangunan infrastruktur Wisata Bukit Kapur Setigi. Permasalahan pada pembangunan Bukit Kapur Setigi yaitu terbatasnya dana dalam melakukan pembangunan, sehingga diperlukan prioritas agar pembangunan dapat optimal. Salah satu alternatif pemecahan masalah tersebut adalah dengan membangun sebuah sistem yang mampu menghasilkan rekomendasi untuk prioritas pembangunan infrastruktur, beserta pencatatan dan pelaporan secara real-time. Hasil yang di dapatkan adalah rekomendasi prioritas pembangunan infrastruktur dari sistem dibuktikan dari hasil penghitungan pada metode Hanlon. Sehingga dalam rangka evaluasi dan bahan pertimbangan dalam menyusun strategi dan pengembangan mutu pelayanan yang lebih baik lagi. [6]

Metode Hanlon mampu memberikan rekomendasi strategi perbaikan, sehingga dengan melakukan analisis dengan metode Hanlon mampu memberikan strategi perbaikan kepada Instalasi Farmasi RSUD Kabupaten Bima guna meningkatkan nilai skor kesesuaian terhadap standar akreditasi pelayanan farmasi. [7]

Metode Hanlon mampu menentukan prioritas permasalahan kesehatan di Desa Simbang Wetan Kabupaten Pekalongan, sehingga penyusunan program kesehatan dalam mengendalikan permasalahan kesehatan dengan tepat dapat terlaksana berdasarkan prioritas dari permasalahan.[8]

Menentukan prioritas masalah kesehatan pada Kabupaten Sukoharjo menggunakan teknik dan metode Hanlon. Alasan memilih metode ini adalah karena sederhana dan mudah dalam perhitungannya serta menggunakan pembobotan dalam menentukan kriteria.[9]

\section{METODE PENELITIAN}

\subsection{Jenis Metode}

Jenis stakeholder yang beragam dengan latar belakang pemahaman tentang sistem informasi yang sangat berbeda mengakibatkan pendekatan penelitian secara kuantitatif tidak akan sesuai. Metode yang dipilih pada penelitian ini menggunakan pendekatan kualitatif untuk mengidentifikasikan solusi yang tepat. Terdapat beberapa komponen yang terkait dengan penelitian ini, yaitu : wawancara semi terstruktur, focus group discussion dan analisis dokumentasi. 
Pendekatan dan jenis penelitian yang dilakukan adalah melalui pendekatan kualitatif. Artinya data yang dikumpulkan bukan berupa angka-angka, melainkan data tersebut berasal dari wawancara dan FGD. Sehingga yang menjadi tujuan dari penelitian kualitatif ini adalah ingin menggambarkan realita empirik di balik fenomena secara mendalam, rinci dan tuntas.[10]

\subsection{Tahapan penelitian}

Pada Gambar 1 adalah urutan dari tahapan penelitian.

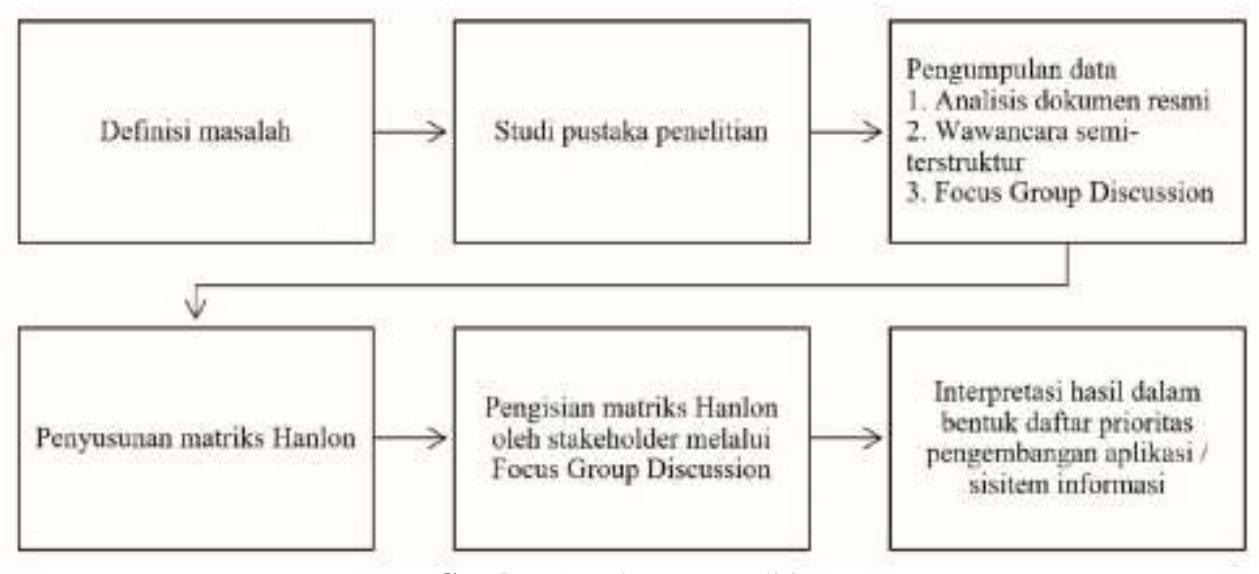

Gambar 1. Tahapan Penelitian

Berdasarkan Gambar 1, berikut penjelasan dari tahapan penelitian yang dilakukan:

a. Definisi masalah

Tahapan ini bertujuan untuk mengumpulkan latar belakang dan menjelaskan permasalahan yang dialami oleh Badan Pengawas XYZ dalam konteks yang terkait dengan prioritas pengembangan perangkat lunak.

b. Studi Pustaka penelitian.

Tahapan ini bertujuan untuk mengumpulkan informasi yang terkait dengan metode dan teknik yang paling tepat untuk melakukan pengumpulan data : jenis dokumen yang harus dianalisis, bentuk wawancara, bentuk focus group discussion, dan stakeholder yang harus disertakan dalam penelitian.

c. Pengumpulan data

Tahapan ini diawali dengan langkah-langkah berikut:

d. Pertama berupa analisis dokumen resmi yang menjadi acuan dasar dalam pelaksanaan tugas Badan Pengawas XYZ. Pelayanan apa yang harus diberikan, Apa yang menjadi Key Performance Index (KPI) utama dan kaitannya dengan sistem informasi/ aplikasi yang mendukung fungsi layanan tersebut.

e. Langkah kedua berupa penentuan dan pelaksanaan wawancara semi-terstruktur dengan para stakeholder untuk mendapatkan masukan dari sudut pandang individual/ group terhadap tingkat urgensi sebuah sistem informasi/ aplikasi.

f. Langkah ketiga berupa Focus Group Discussion (FGD) yang dimoderatori oleh peneliti dengan menyertakan para stakeholder yang terkait. Tujuannya adalah peneliti dapat menyampaikan sebuah tema diskusi yang sudah terfokus (hasil dari kompilasi dua langkah sebelumnya), untuk kemudian diberikan tanggapan, perbaikan, persetujuan, sanggahan oleh para stakeholder. Output dari langkah ini adalah daftar goal yang perlu dicapai dan sistem informasi / aplikasi yang terkait.

g. Peneliti kemudian mengolah data yang ada dalam format matriks Hanlon Kualitatif

Proses pengisian matriks Hanlon menyertakan para stakeholder terkait dalam sesi FGD kedua yang disetujui bersama.

h. Peneliti kemudian melakukan interpretasi akhir terhadap matriks Hanlon yang terbentuk untuk kemudian disusun menjadi sebuah daftar prioritas pengembangan sistem informasi / aplikasi pada Badan Pengawas XYZ.

\section{HASIL DAN PEMBAHASAN}

Penelitian ini berfokus pada penerapan metode Hanlon (Kualitatif) berdasarkan usulan rekomendasi kegiatan yang telah dianalisis serta disusun sebelumnya. Sehingga mempertimbangkan faktor kerahasiaan, dokumen tersebut tidak peneliti bahas dan tampilkan, dan langsung ke penyelesaian permasalahan yang sedang dihadapi.

Hasil akhir adalah susunan komponen-komponen perbaikan yang perlu dilakukan untuk peningkatan kualitas layanan TI di Badan Pengawas XYZ, sebagai berikut: 


\section{A. Implementasi Aplikasi Kuadran 1}

Berdasarkan hasil analisis sistem informasi disertai perhitungan tingkat kepentingan, urgensi (keharusan yang mendesak) dan kompleksitas, terdapat 6 (enam) aplikasi yang direkomendasikan perlu mendapatkan prioritas tinggi untuk dikembangkan oleh Badan Pengawas XYZ, yaitu: Aplikasi BIMTEK, Sistem Informasi Rekrutmen Pengawas XYZ, Sistem Penunjang Keputusan untuk Penentuan Pelaksanaan Sosialisasi Tepat Sasaran, Sistem Informasi Pemantauan/Pengawasan XYZ, Sistem Informasi Pemantauan/Pengawasan XYZ (pengguna masyarakat umum), Sistem Informasi Pemantauan Keputusan dan Desiminasinya.

B. Implementasi Aplikasi Kuadran 2

Aplikasi selanjutnya dengan menggunakan metode analisis yang sama pada aplikasi kuadran 1 , serta perlu mendapatkan prioritas pengembangan menghasilkan 1 aplikasi yaitu Sistem Pengelolaan Informasi Potensi Pelanggaran Berbasis Pengetahuan.

C. Implementasi Aplikasi Kuadran 3

Empat aplikasi yang berada pada kuadran 3 memiliki tingkat kepentingan rendah hingga sedang, serta memiliki kompleksitas rendah, menjadi prioritas pengembangan berikutnya yaitu: Integrated E-arsip, Sistem Informasi Pemantauan Keputusan (Fitur Diseminasi Hasil), Sistem Informasi Kegiatan Badan Pengawas XYZ, dan Sistem Informasi \& Administrasi Audit. Adalah 5 sistem/tata kelola yang perlu mendapatkan prioritas setelah aplikasi kuadran 2.

D. Pembuatan Dokumen Tata Kelola Teknologi Informasi dan Komunikasi Badan Pengawas XYZ

Pada poin ini, berdasarkan hasil wawancara dan observasi terdapat beberapa permasalahan yang muncul. Diantaranya yaitu sulitnya melakukan pemantauan dan pemeliharaan aplikasi yang dikembangkan oleh pihak ketiga, aplikasi dan database yang dikembangkan tidak memiliki standarisasi, hingga belum adanya integrasi data antar aplikasi yang sedang berjalan saat ini. Hal ini sebabkan karena tidak adanya dokumen pedoman formal sebagai acuan bagi setiap unit/satuan organisasi di lingkungan Badan Pengawas XYZ dalam pengelolaan dan pemanfaatan TIK. Sehingga tim konsultan merekomendasikan dibuatnya dokumen Tata Kelola Teknologi Informasi dan Komunikasi Badan Pengawas XYZ.

E. Perbaikan Keamanan Sistem dan Jaringan

Rekomendasi yang didapatkan berdasarkan hasil analisis keamanan sistem dan jaringan Badan Pengawas XYZ menggunakan teknik Penetration Testing. Detil perbaikan yang harus dilakukan dapat dilihat pada laporan spesifik terkait.

F. Peningkatan Pemosisian unit Datin ke level lebih tinggi

Rekomendasi untuk meningkatkan level pemosisian unit Datin saat ini terkait proses mengatur tata kelola IT. Unit yang memiliki level organisasi lebih tinggi akan lebih berhasil untuk membuat, menerapkan, menegakkan, dan melakukan monitoring tata kelola IT yang terintegrasi untuk semua layanan sistem dan teknologi informasi pada Badan Pengawas XYZ, sebaliknya level organisasi yang lebih rendah akan kesulitan untuk menerapkan IT yang terintegrasi karena tidak memiliki kewenangan yang memadai.

G. Pembuatan Dokumen Perencanaan Strategis Sistem Informasi

Rekomendasi penting lainnya terkait dengan perencanaan dan pengembangan jangka panjang SI/TI pada Badan Pengawas XYZ yakni dengan pembuatan dokumen Perencanaan Strategis Sistem Informasi atau biasa disebut IT BluePrint / IT master plan. Merupakan suatu kerangka kerja yang terperinci sebagai landasan dalam pembuatan kebijakan yang meliputi; Penetapan tujuan dan sasaran, penyusunan strategi, pelaksanaan program dan fokus kegiatan, serta langkah-langkah atau implementasi yang harus dilaksanakan oleh setiap unit/ satuan kerja di lingkungan Badan Pengawas XYZ. Hal ini penting untuk menjamin strategi implementasi SI/TI selaras dengan visi, misi, tujuan dan strategi Badan Pengawas XYZ.

H. Peningkatan Skalabilitas Komputasi

Rekomendasi selanjutnya terkait dengan peningkatan kemampuan komputasi. Berdasarkan hasil analisis yang didapat dari wawancara dan observasi, menghasilkan 2 rekomendasi yaitu:

a. Meningkatkan kemampuan kapasitas layanan dari sisi infrastruktur TIK.

b. Meningkatkan kemampuan mitigasi bencana TIK yang mencakup kegagalan/ gangguan infrastruktur fisik (misalnya putus koneksi, bencana kebakaran, kerusakan komponen, dan lain sebagainya) dan logis (misalnya serangan DDoS, ransomware, virus, dsb).

I. Penambahan Personil IT

Rekomendasi untuk meningkatkan jumlah SDM dengan kualitas yang memenuhi syarat dan memiliki kompetensi di bidangnya untuk meningkatkan kualitas layanan Datin Badan Pengawas XYZ dalam menjalankan program kerja. Berdasarkan hasil analisis kebutuhan saat ini dan akan datang, untuk unit Datin direkomendasikan untuk menambah 3 orang personil yang memiliki kompetensi sebagai system analyst sebanyak 1 orang, dan programmer sebanyak 2 orang. 
Available online at http://jom.fti.budiluhur.ac.id/index.php/IDEALIS/index

\subsection{Metode Hanlon Prioritasi Program Kerja}

Berdasarkan rekomendasi usulan kegiatan/program kerja, selanjutnya dilakukan prioritisasi program kerja. Hal ini disebabkan karena tidak sedikitnya rekomendasi program kerja, yaitu sebanyak 9 program yang diharapkan untuk dapat dijalankan. Oleh sebab itu dikarenakan keterbatasan sumber daya yang ada saat ini maka akan lebih mudah jika program kerja tersebut diurutkan berdasarkan mana yang paling prioritas dan prioritas berikutnya.

Metode Hanlon (Kualitatif) adalah metode penentuan prioritas Adapun langkah-langkah penerapan metode ini pada studi kasus sebagai berikut:

1. Membuat matriks masalah/proses/goal yang ingin dibandingkan. Dalam laporan ini akan dibuat matriks dari komponen rekomendasi yang disajikan.

2. Menuliskan komponen rekomendasi pada sumbu vertikal dan sumbu horizontal.

3. Membandingkan (matching) tingkat kepentingan antara rekomendasi yang satu dengan yang lainnya, menggunakan pendekatan :

a. Jika komponen pada sumbu horizontal lebih penting dari komponen pada sumbu vertikal, maka diberikan tanda plus (+).

b. Jika komponen pada sumbu vertikal lebih penting dari komponen pada sumbu horizontal, maka diberikan tanda minus (-).

2. Menjumlahkan tanda plus (+) secara horizontal, dan diletakkan pada kolom total horizontal (+).

3. Menjumlahkan tanda minus (-) secara vertikal, dan diletakkan pada baris total vertikal (-).

4. Pindahkan hasil penjumlahan pada kolom total horizontal (+) di bawah baris total vertikal (-). Proses ini disebut juga copy transpose.

5. Jumlahkan total horizontal(+) dengan total vertikal (-), letakkan pada baris total.

6. Hasil penjumlahan pada baris total merupakan skala prioritas, nilai besar berarti prioritas tinggi, sedangkan nilai rendah adalah prioritas rendah.

Untuk melakukan pembandingan dilakukan kriteria berikut:

1. Kegawatan (Severity)

Besarnya peran komponen yang dibandingkan

2. Urgensi.

Tingkat ketergesaan dari komponen yang dibandingkan.

3. Prasyarat

Ada kemungkinan komponen yang satu harus dilakukan lebih dahulu baru bisa diikuti komponen yang lain.

Hasil pemetaan metode Hanlon tertuang pada Gambar 2. Matrik Prioritas Program Kerja

\begin{tabular}{|c|c|c|c|c|c|c|c|c|c|c|}
\hline Program & A & B & $\bar{C}$ & D & E & $\bar{F}$ & $\bar{G}$ & H & 1 & Horizontal \\
\hline A & $>$ & + & + & - & - & + & - & + & + & 5 \\
\hline B & & $>$ & + & - & - & - & - & + & - & 2 \\
\hline $\mathrm{C}$ & & & 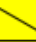 & - & - & - & - & + & - & 1 \\
\hline D & & & & 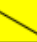 & + & + & + & + & + & 5 \\
\hline$E$ & & & & & 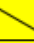 & + & - & + & + & 3 \\
\hline $\mathrm{F}$ & & & & & & 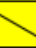 & + & + & + & 3 \\
\hline G & & & & & & & 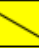 & + & + & 2 \\
\hline $\mathrm{H}$ & & & & & & & & 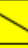 & - & 0 \\
\hline 1 & & & & & & & & & 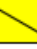 & 0 \\
\hline $\begin{array}{c}\text { Total } \\
\text { Vertikal }\end{array}$ & 0 & 0 & 0 & 3 & 3 & 2 & 4 & 0 & 3 & \\
\hline $\begin{array}{c}\text { Total } \\
\text { Horizontal } \\
\end{array}$ & 5 & 2 & 1 & 5 & 3 & 3 & 2 & $\mathbf{0}$ & 0 & \\
\hline Total & 5 & 2 & 1 & 8 & 6 & 5 & 6 & 0 & 3 & \\
\hline Prioritas & 5 & 7 & 8 & 1 & 3 & 4 & 2 & 9 & 6 & \\
\hline
\end{tabular}

Gambar 2. Matrik Prioritas Program Kerja

\section{Keterangan:}

A : Implementasi Aplikasi Kuadran 1

B : Implementasi Aplikasi Kuadran 2

C : Implementasi Aplikasi Kuadran 3

D : Pembuatan Dokumen Tata Pamong

E : Perbaikan Keamanan Jaringan 
Available online at http://jom.fti.budiluhur.ac.id/index.php/IDEALIS/index

F : Peningkatan Pemosisian Datin ke level lebih tinggi

G : Pembuatan Dokumen Perencanaan Strategis SI

$\mathrm{H}$ : Peningkatan Skalabilitas Komputasi

I : Penambahan Personel IT

Berdasarkan Gambar 2, dapat disimpulkan sebagai berikut:

1. Komponen "Implementasi Aplikasi Kuadran 1" lebih penting terhadap semua komponen lain, kecuali "Pembuatan dokumen tata pamong", "Perbaikan keamanan jaringan", dan "Pembuatan Dokumen perencanaan strategis SI".

2. Komponen "Implementasi Aplikasi Kuadran 2" hanya lebih penting dari "Implementasi Aplikasi Kuadran 3" dan "Peningkatan Skalabilitas Komputasi".

3. Komponen "Implementasi Aplikasi Kuadran 3" hanya lebih penting dari "Peningkatan Skalabilitas Komputasi".

4. Komponen "Pembuatan Dokumen tata pamong" lebih penting dari semua komponen lain.

5. Komponen "Perbaikan Keamanan Jaringan" lebih penting dari semua komponen lain, kecuali "Pembuatan Dokumen tata pamong", dan "Pembuatan Dokumen Perencanaan SI".

6. Komponen "Peningkatan pemosisian Datin ke level lebih tinggi" lebih penting dari semua komponen lain, kecuali "Pembuatan Dokumen tata pamong", dan "Pembuatan Dokumen Perencanaan SI", dan "Implementasi Aplikasi Kuadran 1".

7. Komponen "Pembuatan Dokumen Perencanaan SI" lebih penting dari semua komponen lain, kecuali "Pembuatan Dokumen tata pamong", dan "Peningkatan pemosisian Datin ke level lebih tinggi".

8. Komponen "Peningkatan Skalabilitas Komputasi" tidak lebih penting dari semua komponen lain.

9. Komponen "Penambahan Personnel IT" hanya lebih penting dari komponen "Implementasi Aplikasi Kuadran 2" dan "Implementasi Aplikasi Kuadran 3".

\subsection{Perkiraan Waktu Pelaksanaan Program Kerja}

Setelah mendapatkan prioritas program kerja, selanjutnya melakukan perkiraan waktu untuk melaksanakan keseluruhan program kerja. Program kerja secara keseluruhan dapat ditargetkan dalam kurun waktu 2 tahun. Adapun perkiraan waktu secara kasar untuk penyelesaian rekomendasi tersebut (dapat berubah sesuai kondisi internal organisasi, birokrasi, pihak ketiga dan dukungan anggaran) dapat dilihat pada Tabel 1:

Tabel 1. Durasi Waktu Menyelesaikan Pekerjaan

\begin{tabular}{|c|c|l|c|}
\hline Prioritas & Kode & \multicolumn{1}{|c|}{ Program Kerja } & $\begin{array}{c}\text { Durasi } \\
\text { (Bulan) }\end{array}$ \\
\hline $\mathbf{1}$ & D & Pembuatan Dokumen Tata Pamong & 4 \\
\hline $\mathbf{2}$ & G & Pembuatan Dokumen Perencanaan Strategis SI & 6 \\
\hline $\mathbf{3}$ & E & Perbaikan Keamanan Jaringan & 6 \\
\hline $\mathbf{4}$ & F & Peningkatan Pemosisian Datin ke level lebih tinggi & - \\
\hline $\mathbf{5}$ & A & Implementasi Aplikasi Kuadran 1 & 18 \\
\hline $\mathbf{6}$ & I & Penambahan Personel IT & - \\
\hline $\mathbf{7}$ & B & Implementasi Aplikasi Kuadran 2 & 4 \\
\hline $\mathbf{8}$ & C & Implementasi Aplikasi Kuardan 3 & 16 \\
\hline $\mathbf{9}$ & H & Peningkatan Skalabilitas Komputasi & 3 \\
\hline
\end{tabular}

Sebagai hasil prioritas metode Hanlon kualitatif dan berdasarkan maka berikut adalah perkiraan durasi dan pelaksanaan rekomendasi program kerja dalam kurun waktu 2 tahun yang diturunkan dalam satuan 3 bulanan (triwulan). Sehingga dalam 1 tahun terdapat 4 triwulan (selanjutnya disebut T). Program kerja dan waktu pelaksanaan rekomendasi dapat dilihat pada Tabel 2: 
Available online at http://jom.fti.budiluhur.ac.id/index.php/IDEALIS/index

Tabel 2. Perkiraan Durasi Waktu Pelaksanaan Rekomendasi

\begin{tabular}{|c|c|c|c|c|c|c|c|c|c|c|}
\hline \multirow{2}{*}{ Prioritas } & \multirow{2}{*}{ Kode } & \multirow{2}{*}{ Program Kerja } & \multicolumn{4}{|c|}{ TA 2020} & \multicolumn{4}{|c|}{ TA 2021} \\
\hline & & & T1 & $\mathbf{T 2}$ & T3 & T4 & T1 & T2 & T3 & $\mathbf{T 4}$ \\
\hline 1 & $\mathrm{D}$ & Pembuatan Dokumen Tata Pamong & $\mathrm{X}$ & & & & & & & \\
\hline 2 & G & Pembuatan Dokumen Perencanaan Strategis SI & $\mathrm{X}$ & $\mathrm{X}$ & & & & & & \\
\hline 3 & $\mathrm{E}$ & Perbaikan Keamanan Jaringan & & $\mathrm{X}$ & $\mathrm{X}$ & & & & & \\
\hline 4 & $\mathrm{~F}$ & Peningkatan Pemosisian Datin ke level lebih tinggi & $\mathrm{X}$ & & & & & & & \\
\hline 5 & A & Implementasi Aplikasi Kuadran 1 & & & $\mathrm{X}$ & $\mathrm{X}$ & $\mathrm{X}$ & $\mathrm{X}$ & $\mathrm{X}$ & \\
\hline 6 & I & Penambahan Personel IT & & & & $\mathrm{X}$ & & & & \\
\hline 7 & B & Implementasi Aplikasi Kuadran 2 & & & & & $\mathrm{X}$ & & & \\
\hline 8 & $\mathrm{C}$ & Implementasi Aplikasi Kuadran 3 & & & & & $\mathrm{X}$ & $\mathrm{X}$ & $\mathrm{X}$ & $\mathrm{X}$ \\
\hline 9 & $\mathrm{H}$ & Peningkatan Skalabilitas Komputasi & & & & & & & & $\mathrm{X}$ \\
\hline
\end{tabular}

\section{KESIMPULAN}

Berdasarkan pelaksanaan penelitian ini maka penulis menarik kesimpulan bahwa penerapan metode penelitian kualitatif yang menggunakan pendekatan wawancara semi terstruktur, Focus Group Discussion (FGD) dan prioritasi Hanlon merupakan kombinasi yang efektif untuk memecahkan masalah penentuan prioritasi pada Badan Pengawas XYZ untuk perencanaan masa depan. Dari analisis dan FGD yang dilakukan menghasilkan sebuah daftar prioritas pengembangan sistem informasi atau aplikasi /administratif yang mudah dipahami dan disetujui oleh stakeholder pada Badan Pengawas XYZ.

Metode Hanlon, sangat mudah digunakan, efektif dan cocok diterapkan untuk membantu penentuan prioritas kegiatan (program) khususnya kegiatan pengembangan sistem informasi pada Badan Pengawas XYZ. Dengan cara membandingkan satu kegiatan (program) dengan seluruh kegiatan lainnya berdasarkan tingkat kegawatan dan urgensi. Keputusan sebuah kegiatan lebih utama/penting (diberikan simbol "+”) atau tidaknya (diberikan simbol "-“) dibandingkan dengan kegiatan lain, merupakan hasil kesepakatan para stakeholder pada sesi FGD/ wawancara semi terstruktur (kualitatif) yang dipetakan ke dalam sebuah matriks. Metode Hanlon dapat membantu memecahkan masalah para pengambil keputusan pada Badan Pengawas XYZ dalam penentuan prioritas kegiatan-kegiatan (program) yang direncanakan untuk dijalankan pada program kerja tahunan yang tentunya dibatasi oleh sumber daya biaya (alokasi anggaran), waktu dan sumber daya manusia. Total keseluruhan berdasarkan hasil penjumlahan di matriks pada baris total merupakan skala prioritas, nilai besar berarti prioritas tinggi, sedangkan nilai rendah adalah prioritas rendah. Sehingga setelah total diurutkan secara descending, dapat memperlihatkan kegiatan (program) mana yang menjadi prioritas utama untuk dijalankan. Terdapat 9 (sembilan) usulan rekomendasi kegiatan, dan berdasarkan hasil penerapan metode Hanlon untuk menentukan prioritas, program kerja pembuatan dokumen tata pamong dan perencanaan strategis SI menjadi hal yang utama. Selanjutnya secara berurutan diikuti program perbaikan keamanan jaringan, peningkatan pemosisian Datin ke level lebih tinggi, implementasi aplikasi kuadran 1, penambahan personel IT, implementasi aplikasi kuadran 2, implementasi aplikasi kuadran 3. Sedangkan peningkatan skalabilitas komputasi menjadi program kerja prioritas terakhir.

\section{DAFTAR PUSTAKA}

[1] W. Pramesti and H. Irawan, "Analisis dan Desain Sistem Penunjang Keputusan Berbasis Web dengan Metode Analytical Hierarchy Process (AHP) dan Simple Additive Weighting (SAW) untuk Membantu Penentuan Fasilitator Terbaik pada Yayasan AIDS Indonesia," IDEALIS, vol. 2 No 5, pp. 442-449, 2019.

[2] A. S. Hamdani, A. L. Riani, and G. P. Widodo, "Development Strategy Of Pharmacy Departement Based Accreditation Evaluation In Rsud Dr Moewardi Surakarta By Hanlon Method. Thesis, Pharmacy Faculty, Setia Budi University Surakarta," JISIP, vol. 1, no. 2, pp. 15-19, 2017.

[3] W. C. Adams, "Conducting Semi-Structured Interviews," in Handbook of Practical Program Evaluation: Fourth Edition, 4th ed., K. Wholey, Joseph S., Hatry, Harry P, Newcomer, Ed. New Jersey: Wiley Blackwell, 2015, pp. 492-505.

[4] H. Herlinda, "Prototipe Web KMS pada Universitas Sebagai Sarana Komunikasi Dosen dengan Kerangka 'Tiwana," STRING (Satuan Tulisan Ris. dan Inov. Teknol)., vol. 1, no. 3, p. 325, 2017.

[5] J. W. Creswell and J. D. Creswell, Research Design : Qualitative, Quantitative, and Mixed Methods Approaches, Fifth. Los Angeles: SAGE Publications, 2018.

[6] T. Fidihama, A. T. Wibowo, and N. Yalina, "Sistem Informasi Prioritas Pengembangan Infrastruktur Menggunakan Metode Hanlon Berdasarkan Investasi Warga Desa Sekapuk," JRST (Jurnal Ris. Sains dan Teknol., vol. 4, no. 1, p. 7, 2020.

[7] D. E. S. Bimmaharyanto, A. Fudholi, and G. P. W, "Evaluasi Tingkat Kesesuaian Standar Akreditasi terhadap Pelayanan 
INDONESIA JOURNAL INFORMATION SYSTEM (IDEALIS)

Volume 4, Nomor 1, Januari 2021

ISSN 2684-7280 (online)

Halaman 47-54

Available online at http://jom.fti.budiluhur.ac.id/index.php/IDEALIS/index

Farmasi dan Strategi Perbaikan dengan Metode Hanlon di RSUD Kabupaten Bima,” JIME, vol. 3, no. 2, pp. 209-215, 2017.

[8] R. Vita and N. Latif, "Identifikasi Permasalahan Kesehatan di Desa Simbang Wetan Kecamatan Buaran Kabupaten Pekalongan Tahun 2015," J. Pena Med., vol. 5, no. 1, pp. 71-77, 2015.

[9] A. Hasanuddin and Muzaki, “Analisis Masalah Kesehatan Di Kabupaten Sukoharjo," UNM Environ. Journals, vol. 2, no. 3, pp. 92-97, 2019.

[10] D. M. A. Lexy J. Moleong, Metodologi Penelitian Kualitatif (Edisi Revisi). Bandung: PT. Remaja Rosdakarya, 2019. 